\title{
A helikopter teher-UAV-tól a kínai AT200-as teherszállító robotrepülőgépig
}

A pilóta nélküli repülőgépekkel történő légi ellátás alkalmazását a nyugati haderők már megkezdték. Napjainkban számos fejlesztés célozza a helikopterek robot üzemmódban történő repülésének megvalósítását. Mivel a robotizált helikoptereknél nincs szükség fedélzeten tartózkodó pilótára és egyes, a pilótához köthető rendszerek is elhagyhatók (vizuális leolvasású fedélzeti műszerek, kormányszervek, ülések stb.) így a - típustól függően - mintegy 10-20\%-kal növekszik a repülőeszköz belső teherterének mérete, illetve a szállítható hasznos tömeg.

Elsőként az amerikai haderő lépett ezen a területen, amikor kifejlesztették a Kaman K-Max robothelikoptert. Az $1500-2700 \mathrm{~kg}$ hasznos terhelhetőségű könnyű helikopter feladata lőszer, üzemanyag és más utánpótlás kijuttatása a partra szálló hajóegységről a hídfőben tartózkodó, partra szállt tengerészgyalogos csapatokig. Repülését GPS koordináták szerint automatikus üzemmódban, operátor segítségével vagy vegyes üzemmódban (pl. leszálló fázisban

ÖSSZEFOGLALÁS: A pilóta nélküli repülőgépekkel történő légi ellátás megvalósitását a nyugati haderők már gyakorlatban is tesztelik. Rajtuk kívül több országban folytatnak fejlesztéseket ennek a célnak a megvalósítása érdekében. A cikk három, ebbe a kategóriába tartozó eszközt, két amerikai forgószárnyas és egy merevszárnyas kínai UAV-ot mutat be.

KULCSSZAVAK: pilóta nélküli repülőgép, légi ellátás, robotizált helikopter, teher-UAV, Kaman K-Max, Northrop Grumman MQ-8, AT200 operátor által átvett kézi irányítás) végezheti. A mindössze 2200 kg szerkezeti tömegű könnyű helikopter teheremelő képességét valamelyest javította a pilóta elhagyása. Jelenlegi ismereteink szerint csapatpróbán tesztelik. 2011-ben két példányt vett át az amerikai tengerészgyalogság, amelyeknél a CQ-24A típusjelzést alkalmazták. Afganisztánban 2500 tonna anyagot mozgattak meg.

Az Egyesült Államok Haditengerészete a Northrop Grumman cég által gyártott $M Q$-8-as „Fire Scoth” helikopter UAV-t alkalmazza, amely képes fedélzeti fegyverek hordozására, valamint a mélységben tevékenykedő csoportok részére utánpótlás szállítására is. [1] A típus új változatát négylapátos forgószárny jellemzi, ami biztosítja a nagyobb emelőerőt és hosszabb repülési időtartamot, valamint a kisebb zajszintet is. A maximális hasznos terhelhetőség jelenleg 272 kg. Az eszköz maximális repülési ideje, kis terheléssel 8 óra. A cég képviselői - a megfelelő hatótávolság elérése érdekében - $91 \mathrm{~kg}$ tömegú vészutánpótlási csomagok szállítását javasolják, amelyek külső függesz-

ABSTRACT: Air supply by the use of unmanned aerial vehicles is currently being tested by the Western armed forces. Besides them, in several countries, developments are being conducted in order to realize this ambition. This article describe three equipment of this category: two American rotary wing UAVs and one Chinese fixed wing drone.

KEY WORDS: unmanned aerial vehicle, air supply, robotized helicopter, cargo UAV, Kaman K-Max, Northrop Grumman MQ-8, AT200

\footnotetext{
* Mérnök, a Haditechnikai Intézet ny. tanácsosa, a Haditechnika folyóirat korábbi szerkesztője, ORCID: 000-0002-2008-7997
} 


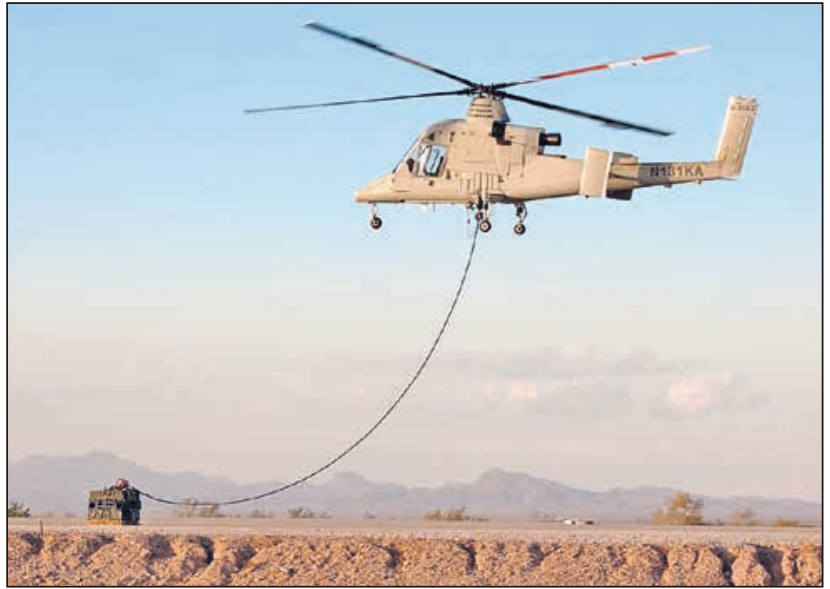

2. ábra. A Kaman K-Max robothelikopter kísérleti példánya, teheremelö sodronnyal

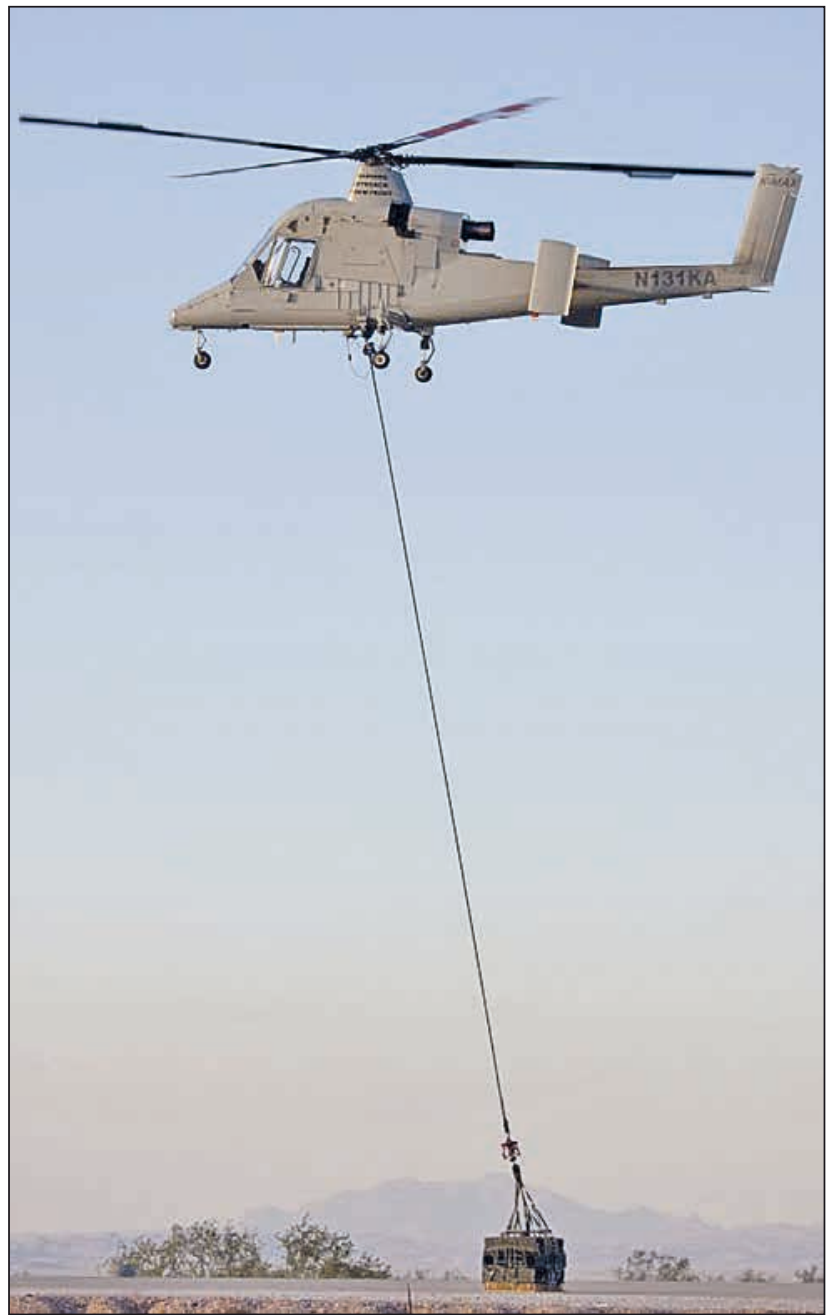

3. ábra. Egy Kaman K-Max kísérleti példánya teheremelés közben

tésben lennének szállíthatók, s az UAV programozható lenne az utánpótlás bármely megadott helyre és időben történő lerakására, vagy ejtőernyős ledobására. A Fire Scout UAV további alkalmazását a szárazföldi vagy tengeri kutató-mentő feladatok végrehajtása képezi, túlélést biztosító felszerelések ledobásával. [2]

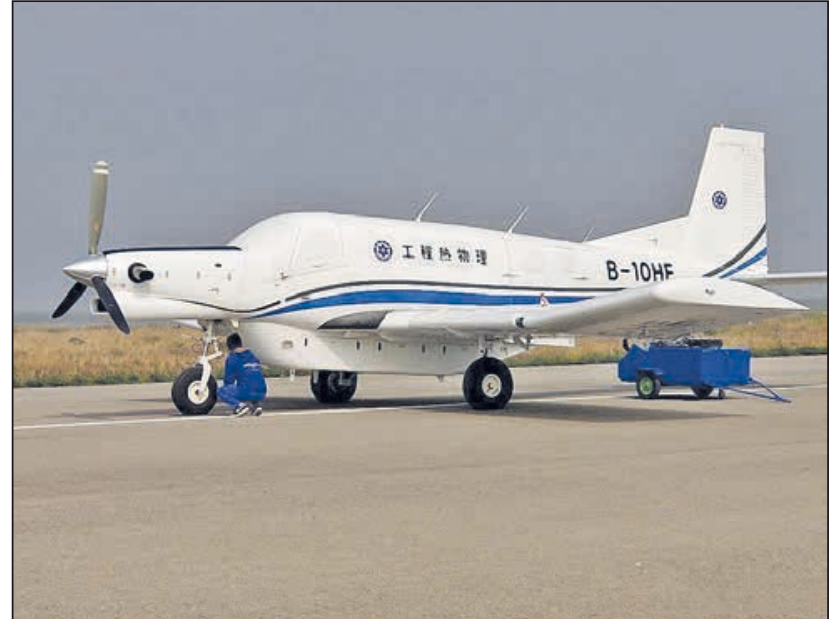

4. ábra. A 2006-os Chengdu-i kiállításon bemutatott AT200-as teherszállító robotrepülögép modell. Az elsó futószárnál guggoló férfi jól mutatja a gép méretét

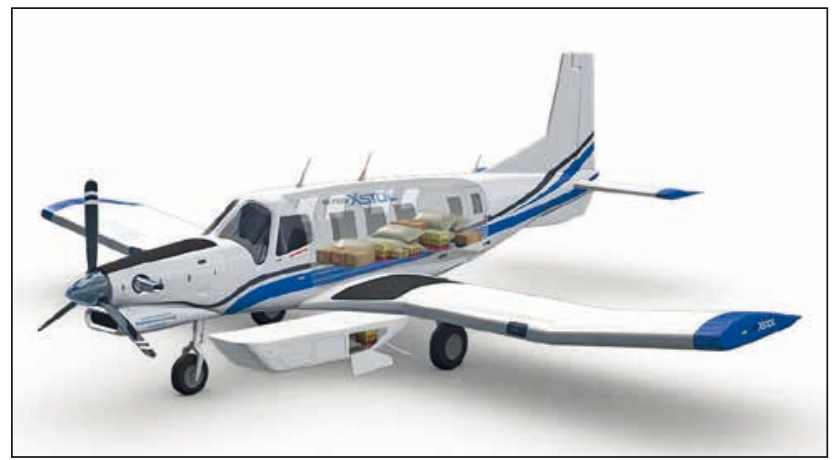

5. ábra. Számítógépes grafika az újzélandi PAC P-750 XSTOL repülőgépröl. A gép sárkányát felhasználva fejlesztették ki az AT200-as kínai teher-UAV-ot. A képen jól látható a tehertér, a has alatti gondola és felhasználásuk opciós lehetőségei

2017. október 26-án végezte el első felszállását az AT200 típusjelű kínai UAV repülőgép a Senhszi tartományban fekvő gyár repülőteréről. Ez a világ első ismert, nagy méretű pilóta nélküli teherszállító robotrepülőgépe. Hivatalosan a Kínai Tudományos Akadémia Termofizikai Intézete fejlesztette ki. (Az alapgép az új-zélandi PAC P-750 XSTOL repülőgép volt.) Egyelőre hangsúlyozottan polgári jellege van, lajstromjele B-10HE. Ami ismert róla: hossza 11,84 méter, fesztávolsága 12,4 méter, maximális felszálló tömege 3400 kg, elvileg a hasznos teher 1500 kg, a rakodótér $10 \mathrm{~m}^{3}$-es. Repülési idő 8 óra lehet, hatótávolsága több mint 2000 km. Légcsavaros gázturbinával rendelkezik, amelynek típusa: Pratt \& Whitney Canada PT6A, teljesítménye $750 \mathrm{LE}$. A futómű behúzható. A has alatti konténer szerepe ugyancsak ismeretlen. Angol szakirodalmi adatok szerint a Dél-kínai-tengeren a korallzátonyokra épített mesterséges szigetek ellátására szánják.

\section{ForRÁsOK}

[1] A Fire Scout forgószárnyas UAV eszköz csatlakozik a hadsereghez. Aviation Week \& Space Technology 2003. október, 66. o.;

[2] Turcsányi Károly - Hegedűs Ernő: A légideszant II., 1945-2010. Debrecen, Puedlo Kiadó, 2011. 231 p. 